\section{Physical Properties of Ground Fresh Rice Hulls and Sphagnum Peat Used for Greenhouse Root Substrates}

\author{
Paolo Sambo ${ }^{1,3}$, Franco Sannazzaro ${ }^{1}$, and Michael R. Evans ${ }^{2}$
}

ADDITIONAL INDEX WORDs. media physics, root media, air-filled pore space, waterholding capacity

SuMmARY. Ground fresh rice (Oryza sativa) hull materials were produced by grinding whole fresh rice hulls and passing the resulting product through a 1-, 2-, 4- or 6-mmdiameter screen to produce a total of four ground rice products $(\mathrm{RH}, \mathrm{RH} 2, \mathrm{RH} 4$, and RH6, respectively). The physical properties and water release characteristics of sphagnum peatmoss (peat) and the four ground rice hull products were evaluated. All of the ground rice hull products had a higher bulk density $(\mathrm{Bd})$ than peat, and as the grind size of the rice hull particle decreased, Bd increased. Peat had a higher total pore space (TPS) than all of the ground rice hull products except for RH6. As grind size decreased, the TPS decreased. Peat had a lower air-filled pore space (AFP) than all of the ground rice hull products and as the grind size of the rice hull products decreased, AFP decreased. Peat had a higher water holding capacity (WHC) than all of the ground rice hull products. Grind sizes RH4 and RH6 had similar WHC, whereas RH1 and RH2 had a higher WHC than RH4 and RH6. Peat, RH4, and RH6 had similar available water content (AVW), whereas RH2 had higher AVW than these materials and RHI had the highest AVW. However, peat had the lowest AVW and easily available water (EAW) as a percentage of the WHC. The ground rice hull products RH1 and RH2 had the highest AVW and EAW of the components tested. Peat had the highest water content at container capacity. As pressure was increased from 1 to $5 \mathrm{kPa}$, peat released water more slowly than any of the ground rice hull products. The $\mathrm{RH} 1$ and $\mathrm{RH} 2$ ground hull products released water at a significantly higher rate than peat, but RH4 and RH6 released the most water over these pressures. For all rice hull products, most water was released between 1 and 2 $\mathrm{kPa}$ pressure. The rice hull products $\mathrm{RH} 1$ and $\mathrm{RH} 2$ had physical properties that were within recommended ranges and were most similar to those of peat.

S oilless root substrates (substrates) are commonly used in the production of containerized greenhouse crops. These substrates may be composed of a single material such as rockwool or block-cut peat, but in most cases, they are composites formulated by the blending of two or more components such as peat, composted bark, perlite, whole rice hulls, or vermiculite (Hanan, 1998; Nelson, 2003). Substrates are designed to have appropriate physical properties for specific crops and growing conditions. The components used to formulate the substrate and the proportions of the components may be altered to change the physical properties of the substrate as desired (Bunt,

\footnotetext{
This project was supported by the Arkansas Agricultural Research and Extension Service.

${ }^{1}$ Department of Environmental Agronomy and Crop Production, University of Padova, Via dell'Università, 16, 35020, Legnaro (PD), Italy

${ }^{2}$ Department of Horticulture, Plant Sciences Room 316, University of Arkansas, Fayetteville, AR 72701

${ }^{3}$ Corresponding author. E-mail: paolo.sambo@
} unipd.it.
1988). Total pore space, air-filled pore space, waterholding capacity, available water content, easily available water, and bulk density are typically the physical properties of greatest interest for substrates to be used in greenhouse crop production.

Peat is one of the most common components used in the formulation of root substrates (Cattivello, 1991). Environmental concerns (Barkham, 1993; Buckland, 1993; Robertson, 1993) in the European Union and cost in markets such as Japan that are far from commercial peat sources have generated significant interest in the development of new substrate components that could serve as alternatives to peat in substrates.

Most research on the development of new substrate components that could serve the same purpose in the root substrate as peat has been focused on agricultural, industrial, and municipal waste products. Among these products were coconut (Cocos nucifera) coir (Evans and Stamps, 1996), cotton (Gossypium hirsutum) gin waste (Wang, 1991), waste paper products (Chong and Cline, 1993; Raymond et al., 1998), composted rice hulls (Laiche and Nash, 1990), kenaf (Hibiscus cannabinus) (Wang, 1994), feather fiber (Evans, 2004), municipal sewage sludge (Klock-Moore, 1999, 2001), composted yard waste (Beeson, 1996), and various composted animal manures (Tyler et al., 1993). Some of these materials were not produced in large enough quantities to impact the market, whereas others were too expensive for their intended use. Some of these materials have proven to be unsuitable because of their high degree of variability and their likelihood of containing contaminants such as metal fragments, glass, lead, and mercury, whereas others have been successfully used locally, regionally, or in niche markets.

Rice hulls are a byproduct of the rice milling industry. Rice is produced over large areas of Asia, and in the United States, it is produced primarily in Arkansas, Texas, Louisiana, Mississippi, and California. In Europe, most rice is produced in Italy's Po River Valley. The yield of rice hulls was reported to be $\approx 20 \%$ by weight. Because $350,000 \mathrm{mg}$ of rice was produced in Italy in 2003 (Ente Nazionale Risi, 2006), the resulting rice hulls would be $\approx 87,500 \mathrm{mg}$. Rice production in the United States was estimated to be $\approx 7.5$ million tons [U.S. Department of Agriculture

\begin{tabular}{llll}
\hline $\begin{array}{l}\text { Units } \\
\begin{array}{l}\text { To convert U.S. to SI, } \\
\text { multiply by }\end{array}\end{array}$ & U.S unit & SI unit & $\begin{array}{l}\text { To convert SI to U.S., } \\
\text { multiply by }\end{array}$ \\
\hline 1 & $\%$ & $\mathrm{~cm}^{3} / 100 \mathrm{~cm}^{3}$ & 1 \\
100 & bar & $\mathrm{kPa}$ & 0.01 \\
2.54 & inch $(\mathrm{es})$ & $\mathrm{cm}$ & 0.3937 \\
25.4 & inch $(\mathrm{es})$ & $\mathrm{mm}$ & 0.0394 \\
28.3495 & $\mathrm{oz}$ & $\mathrm{g}$ & 0.0353 \\
1.7300 & $\mathrm{oz} / \mathrm{inch}^{3}$ & $\mathrm{~g} \cdot \mathrm{cm}^{-3}$ & 0.5780 \\
0.9072 & ton $(\mathrm{s})$ & $\mathrm{Mg}$ & 1.1023 \\
$\left({ }^{\circ} \mathrm{F}-32\right) \div 1.8$ & ${ }^{\circ} \mathrm{F}$ & ${ }^{\circ} \mathrm{C}$ & $\left(1.8 \times{ }^{\circ} \mathrm{C}\right)+32$ \\
& & &
\end{tabular}


(USDA), 2007], and worldwide production of rice was estimated to be 474 million tons per year. This would translate into 1.89 million and 118 million tons of rice hulls per year in the United States and worldwide, respectively. Therefore, rice hulls are an abundant and readily available material throughout much of the world.

Evans and Gachukia (2007) demonstrated that whole fresh rice hulls, because of their relatively large particle size, could be used in substrates to provide drainage and airfilled pore space. They reported that no nitrogen depletion occurred as a result of the incorporation of the fresh rice hulls and that plant growth was comparable in substrates where perlite was replaced with an equivalent amount of fresh rice hulls (Evans and Gachukia, 2004). Calderon (2001) reported that fresh rice hulls were commonly used for hydroponic cultivation in South America.

The objective of this research was to evaluate the physical properties of different sizes of fresh rice hull particles produced by grinding and screening and to determine if the ground rice hulls had similar properties to peat and if they would be suitable as an alternative to peat in substrates to be used for greenhouse crop production.

\section{Materials and methods}

Fresh whole rice hulls were obtained from Cooperativa Produttori Riso (La Pila, Isola della Scala, Verona, Italy). Sphagnum peat (Van Post and Bragg scale of $\mathrm{H} 2-\mathrm{H} 4$ as reported in Dammon and French, 1987) was obtained from Klasmann Deilmann GmbH (Gross Hesepe, Germany). Ground rice hull materials were produced by grinding whole fresh rice hulls in a rotary mill and passing the resulting product through a 1-, 2-, 4- or 6-mm-diameter screen to produce a total of four ground rice products ( $\mathrm{RH} 1, \mathrm{RH} 2, \mathrm{RH} 4$, and RH6, respectively).

The particle size distribution of the peat and ground rice hull products were determined by sieving dry 100 -g samples of each material on a series of sieves with openings ranging from $5 \mathrm{~mm}$ to $0.5 \mathrm{~mm}$ for $2 \mathrm{~min}$. The amount of material collected in each screen was weighed and the percentage of material collected on each screen was calculated as a percentage $(\mathrm{w} / \mathrm{w})$ of the whole sample.

Peat and rice hull products were dried in an oven at $65^{\circ} \mathrm{C}$ for $48 \mathrm{~h}$. The materials were then packed into brass cylinders that were $80 \mathrm{~mm}$ diameter and $51 \mathrm{~mm}$ tall, and the ends of the cylinder were sealed with cheesecloth. Samples were saturated with water and water retention curves of the samples were developed using a tensiometric box and pressure plates according to methods described by the International Substrates Manual (Frank-Paul and Berg, 2000). Samples were subjected to head pressures of $1,1.5,2,3,5,7$, and $10 \mathrm{kPa}$ (De Boodt and Verdonck, 1972). The volume of water held from 0 to $1 \mathrm{kPa}$ of pressure was considered to be the AFS at container capacity, and the water held at a pressure of $1 \mathrm{kPa}$ was considered to be total water holding capacity (WHC). Water held from 1 to $10 \mathrm{kPa}$ was considered to be available water content (AVW), whereas water held from $\mathrm{l}$ to $5 \mathrm{kPa}$ was considered to be easily available water (EAW) (Bunt, 1988; De Boodt and Verdonck, 1972). Samples were dried in an oven at $105{ }^{\circ} \mathrm{C}$ until they reached a constant weight. The dry weight was subtracted from the weight at container capacity to determine total WHC. The AVW and EAW were divided by the total WHC to determine the percent of water available (PWA) and easily available (PEW), respectively. The dry weight of the substrate was divided by the total cylinder volume to determine bulk density (Frank-Paul and Berg, 2000).

For each test material, five cylinders were tested with a cylinder serving as a replication. Water retention curves were plotted with water content (\% by volume) versus pressure. An analysis of variance was conducted to determine if bulk density (Bd), total pore space (TPS), WHC, AVW, and EAW differed significantly among the substrate materials. Where significant differences occurred, a least significant difference mean separation test was conducted to determine differences between specific means.

\section{Results and discussion}

The rice hull product produced using a $\mathrm{l}$-mm-diameter screen ( $\mathrm{RHl})$ was composed primarily of particles with a diameter of less than $0.5 \mathrm{~mm}$ (Fig. 1). As the screen size was increased, the resulting rice hull products (RH2, RH4, and RH6) contained an increasing proportion of larger particles and a decreasing proportion of smaller particles. Peat had the highest proportion of particles exceeding $5 \mathrm{~mm}$.

All of the ground rice hull products had a higher Bd than peat (Table 1 ). As the grind size of the rice hull particles decreased, Bd increased. Peat had a higher TPS than all of the

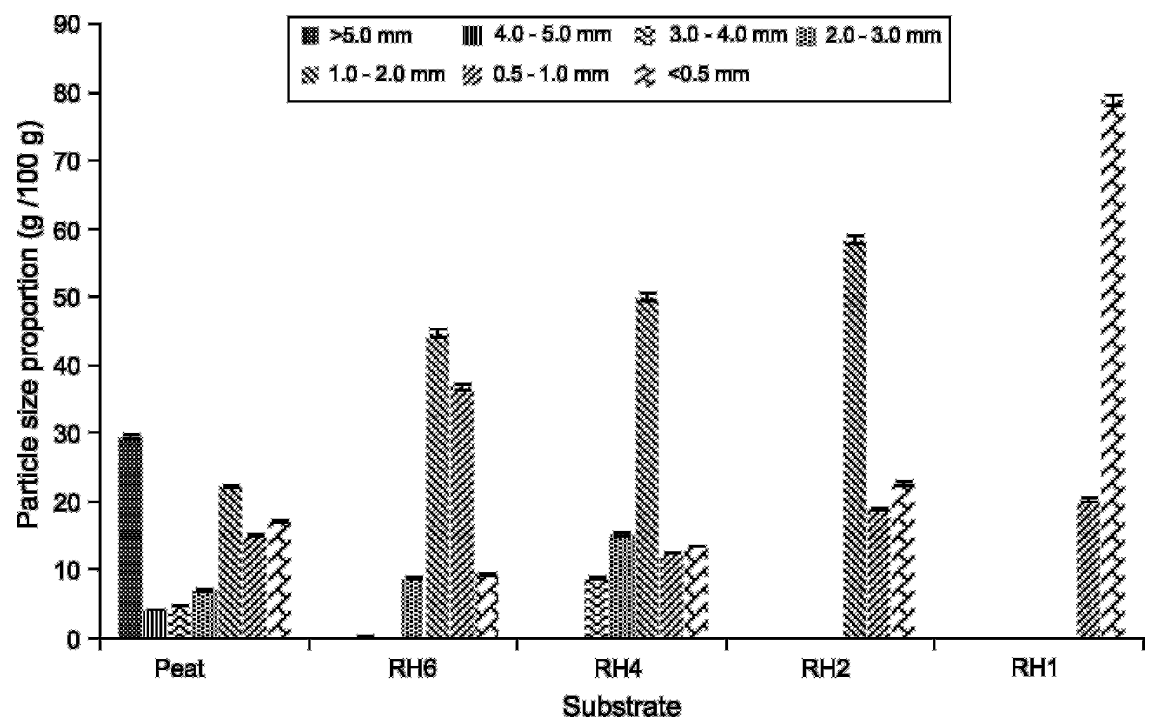

Fig. 1. Particle size distribution for peat and ground rice hull products. RHI, $\mathrm{RH} 2, \mathrm{RH} 4$, and $\mathrm{RH} 6$ indicate particles obtained by passing ground rice hulls through a 1-, 2-, 4- or 6-mm-diameter screen, respectively. Error bars represent the SE; $1 \mathrm{~g} / 100 \mathrm{~g}=1 \%, 1 \mathrm{~mm}=0.0394$ inch. 


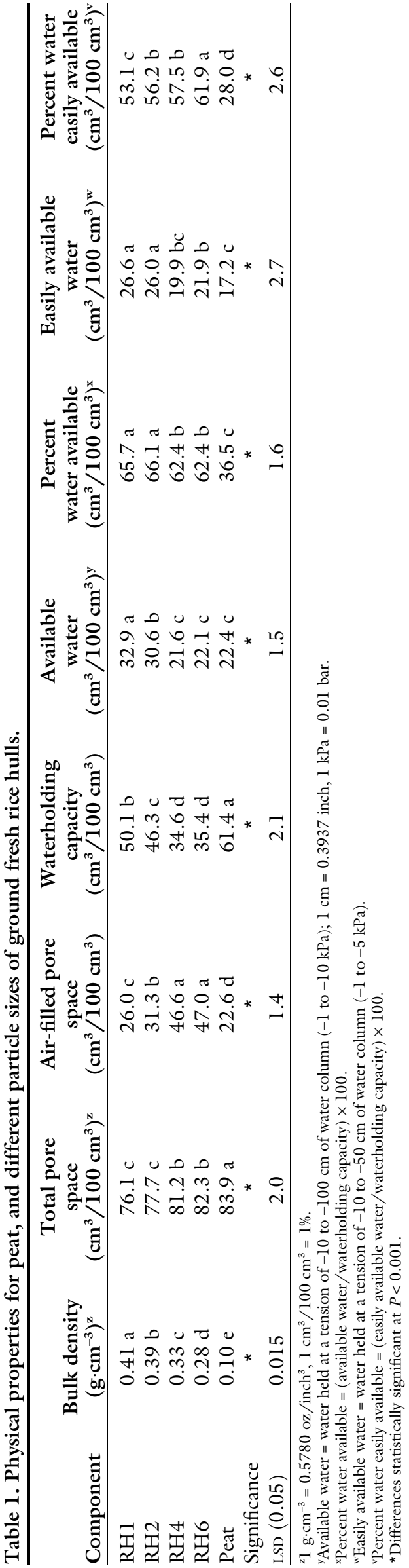

ground rice hull products except for RH6. As grind size decreased, the TPS decreased so that RH6 had a higher TPS than RH1 and RH2. The rice hull products $\mathrm{RH}$ and $\mathrm{RH} 2$ had similar TPS. Peat had a lower air-filled pore space (AFP) than all of the ground rice hull products, and as the grind size of the rice hull products decreased, AFP decreased.

The WHC was inversely related to AFP. Peat had a higher WHC than all of the ground rice hull products (Table 1). The rice hull products RH4 and RH6 had similar WHC. Both $\mathrm{RH} 1$ and $\mathrm{RH} 2$ had WHC higher than RH4 and RH6. The $\mathrm{RH} l$ had the highest WHC of all of the components tested. Peat, RH4, and RH6 had similar AVW, whereas RH2 had higher AVW than these materials and RHl had the highest AVW. Peat had the lowest PWA. The RH4 and RH6 ground rice hulls had a similar PWA, whereas RHI and RH2 had the highest PWA of all of the components. Peat had the lowest EAW of all of the substrate components, whereas RH4 and RH6 had similar EAW. The ground rice hull products $\mathrm{RH}$ l and $\mathrm{RH} 2$ had the highest EAW. Peat had the lowest PEW, whereas RH1 and RH2 had the highest PEW of all of the components.

Peat had the highest WHC (1 $\mathrm{kPa}$ pressure). As pressure was increased from $\mathrm{l}$ to $5 \mathrm{kPa}$, peat released water more slowly than any of the ground rice hull products (Fig. 2). The RHl and RH2 ground hull products released water at a significantly higher rate than peat, but RH4 and RH6 released the most water over these ranges of pressures. For all rice hull products, most water was released between 1 and $2 \mathrm{kPa}$ pressure. Additional water was released more slowly over the range of pressures from 2 to $10 \mathrm{kPa}$. At 10 $\mathrm{kPa}$ pressure, peat held the most water of all the substrate components, whereas $\mathrm{RH} 1, \mathrm{RH} 2$, and $\mathrm{RH} 4$ had similar water content at this pressure. The RH6 had the lowest water content at $10 \mathrm{kPa}$ pressure.

The physical properties of the ground rice hull products compared with one another can be explained as a function of average particle size. As particle size decreased, particles packed more closely together, and this resulted in a higher $\mathrm{Bd}$ and a 


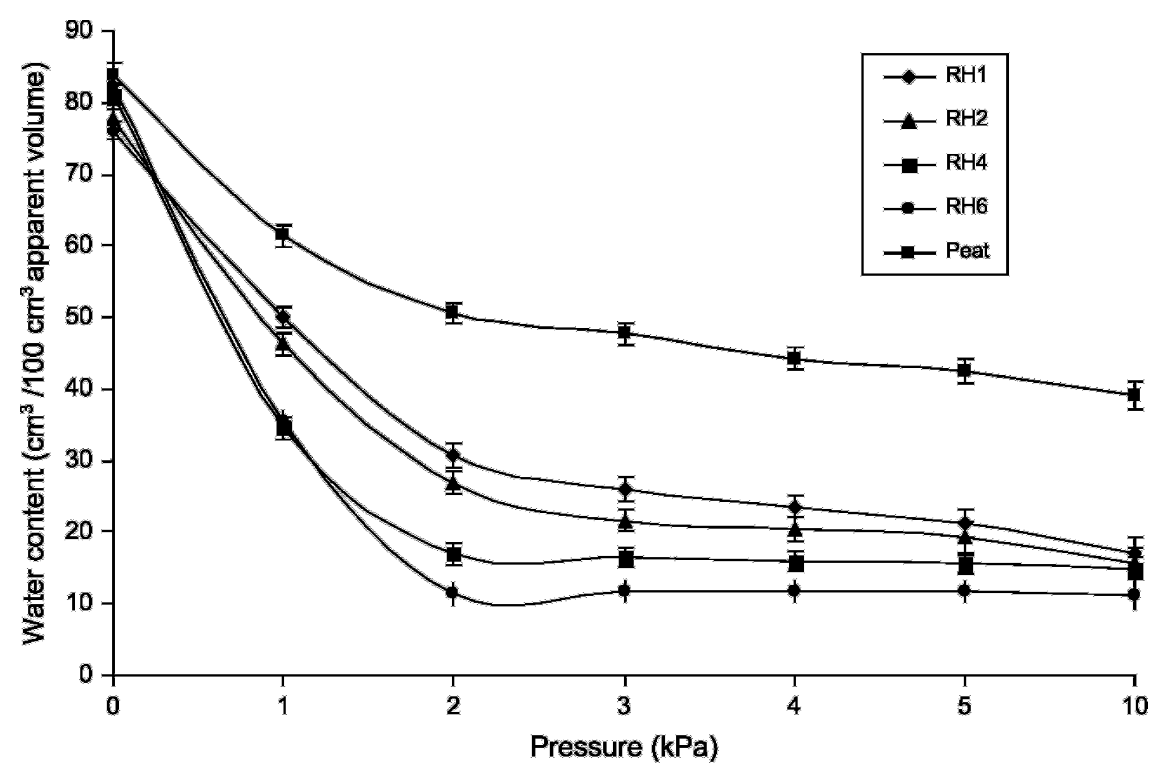

Fig. 2. Water release curves for sphagnum peat, whole fresh rice hulls, and various grind sizes of ground fresh rice hulls. $\mathrm{RH} 1, \mathrm{RH} 2, \mathrm{RH} 4$, and $\mathrm{RH} 6$ indicate particles obtained by passing ground rice hulls through a 1-, 2-, 4- or 6-mm-diameter screen, respectively $(1 \mathrm{~mm}=0.0394 \mathrm{inch})$. Error bars represent the $\mathrm{SE} ; 1 \mathrm{~cm}^{3} / 100 \mathrm{~cm}^{3}=1 \%, 1 \mathrm{kPa}=0.01$ bar.

lower TPS. Additionally, as the average particle size decreased, average pore size would have decreased and the number of micropores would have increased. These smaller pores would tend to remain water-filled at container capacity and this would result in an increase in WHC and a decrease in AFP, which is what was observed for the ground rice hull products.

Peat had a higher proportion of larger particles than any of the ground rice hull products and thus, as expected, it had the highest TPS. However, it had the lowest AFP and the highest WHC. This was likely because although the particles of peat were relatively large in comparison with the ground rice hull products, peat is a fibrous material. In addition to fibers, peat contains leaf remnants from its plant origin. Although the peat particle is large, its structure creates many small pores within the larger structure and these small pores ultimately retain water rather than draining and being air-filled at container capacity. Additionally, the numerous small pores created by the fibers and leaf remnants of the peat would have held water more tightly against pressure resulting in the difference in the water retention curves of the rice hull products and peat.

None of the ground rice hull products had the same physical properties as peat. However, all of the ground rice hull products provided a higher AFP and AVW than the peat. Arnold Bik (1983) and Boertje (1984) recommended a minimum of $85 \%$ TPS and at least $45 \%$ water-filled pore space. Bunt (1988) recommended an AFP of at least $10 \%$ to $20 \%$. Jenkins and Jarrell (1989) proposed optimal ranges of $60 \%$ to $75 \%$ for TPS, $50 \%$ to $65 \%$ for WHC, and $10 \%$ to $20 \%$ for AFP. All of the ground rice hull products were within the recommended ranges for $\mathrm{Bd}$, TPS, and AFP. Although RHI and RH2 had a lower WHC than peat, their WHC were within the recommended ranges, and they had higher AVW than peat. Therefore, the ground rice hull products $\mathrm{RHI}$ and RH2 would be best suited as root substrate components intended to be used as an alternative to peat in the root substrate.

\section{Literature cited}

Arnold Bik, R. 1983. Substrates in floriculture. Proc. XXI Intl. Hort. Congr. 2:811-822.

Barkham, J.P. 1993. For peat's sake: Conservation or exploitation. Biodivers. Conserv. 11:1877-1887.

Beeson, R.C., Jr. 1996. Composted yard waste as a component of container substrates. J. Environ. Hort. 14:115-121.
Boertje, G.A. 1984. Physical laboratory analyses of potting composts. Acta Hort. 150:47-50.

Buckland, P.C. 1993. Peatland archeology: A conservation resource on the edge of extinction. Biodivers. Conserv. 2:513527.

Bunt, A.C. 1988. Media and mixes for container grown plants. Unwin Hyman, London, UK.

Calderon, F. 2001. Que son los cultivos hidroponicos y el porque de la hidroponia, p. 1-20. In: Calderon, F. (ed.). Memorias, Primero curso de hidroponia para la floricultura. 31 May-2 June 2001. Bogata, Colombia.

Cattivello, C. 1991. Physical parameters in commercial substrates and their relationships. Acta Hort. 294:183-195.

Chong, C. and R.A. Cline. 1993. Response of four ornamental shrubs to container substrate amended with two sources of raw paper mill sludge. HortScience 28:807-809.

Dammon, A.W.H. and T.W. French. 1987. The ecology of peat bogs of the glaciated northeastern United States. U.S. Fish and Wildlife Service Biol. Rpt. 85(7.16).

De Boodt, M. and O. Verdonck. 1972. The physical properties of the substrates in horticulture. Acta Hort. 26:37-44.

Ente Nazionale Risi. 2006. XXXIX Relazione Annuale Anno 2006. Uffici di Direzione di Ente Nazionale Risi, Milan, Italy.

Evans, M.R. 2004. Processed poultry feather fiber as an alternative to peat in greenhouse crops substrates. HortTechnology 14:176-179.

Evans, M.R. and M. Gachukia. 2004. Fresh parboiled rice hulls serve as an alternative to perlite in greenhouse crop substrates. HortScience 39:232235.

Evans, M.R. and M.M. Gachukia. 2007. Physical properties of sphagnum peatbased root substrates amended with perlite or parboiled fresh rice hulls. HortTechnology 17:312-315.

Evans, M.R. and R.H. Stamps. 1996. Growth of bedding plants in Sphagnum peat and coir dust-based substrates. J. Environ. Hort. 14:187-190.

Frank-Paul, T. and E.R. Berg. 2000. International substrates manual. Elsevier, Doetinchem, The Netherlands.

Hanan, J.J. 1998. GreenhouseAdvanced technology for protected horticulture. CRC Press, Boca Raton, FL. 


\section{Research Reports}

Jenkins, J.R. and W.M. Jarrell. 1989. Predicting physical and chemical properties of container mixtures. HortScience 24:292-295.

Klock-Moore, K.A. 1999. Bedding plant growth in greenhouse waste and biosolid compost. HortTechnology 9:210-213.

Klock-Moore, K.A. 2001. The effect of controlled release fertilizer application rates on bedding plants containing compost. Compost Sci. Util. 9:215-220.

Laiche, A.J., Jr. and V.E. Nash. 1990. Evaluation of composted rice hulls and a lightweight clay aggregate as components of container-plant growth media. J. Environ. Hort. 8:14-18.
Nelson, P.V. 2003. Greenhouse operation and management. 6th ed. Prentice Hall, Upper Saddle River, NJ.

Raymond, D.A., C. Chong, and R.P. Voroney. 1998. Response of four container grown woody ornamentals to immature composted media derived from waxed corrugated cardboard. Compost Sci. Util. 6:67-74.

Robertson, R.A. 1993. Peat, horticulture and environment. Biodivers. Conserv. 2:541-547.

Tyler, H.H., S.L. Stuart, T.E. Bilderback, and K.B. Perry. 1993. Composted turkey litter: II. Effect on plant growth. J. Environ. Hort. 11:137-141.
U.S. Department of Agriculture. 2007. Crop production 2006 summary. U.S. Dept. Agr., Natl. Agr. Stat. Serv., Washington, DC.

Wang, Y. 1991. Evaluation of media consisting of a cotton waste for the production of tropical foliage species. J. Environ. Hort. 9:112-115

Wang, Y.T. 1994. Using ground kenaf stem core as a major component of container media. J. Amer. Soc. Hort. Sci. 19:931-935. 